\title{
Obituary
}

HORMONE

RESEARCH IN

PAEDIATRICS
Horm Res Paediatr 2016;85:219-220

DOI: $10.1159 / 000444667$
Published online: March 12, 2016

\section{Primus-Eugen Mullis, November 1954 - January 2016}

Prof. Primus-Eugen Mullis sadly passed away on January 12,2016 . He was an outstanding paediatric endocrinologist who will be greatly missed by his family, colleagues and many friends throughout the world. He was well renowned internationally and was in much demand as a speaker as well as a chairperson and organiser of meetings.

Primus was born on November 10, 1954, in Walenstadt, Switzerland. His mother was of Swedish descent, and his father was Swiss. At the age of 13, Primus was sent to the catholic boarding school of Disentis, Graubünden, Switzerland, where he spent 7 years until his graduation. During these school years, he received a very broad humanistic education; this included studying Latin and ancient Greek with a respective background in history and arts. Primus was a good student and very much liked by his schoolmates for his kind and witty nature. He was also a very sporty young man who even performed in alpine skiing at competition level during his adolescent years. He loved the Swiss mountains and spent a considerable amount of his precious leisure time in nature, either hiking, mountaineering or alpine/cross-country skiing.

After successful graduation from high school, he decided to apply for medical school, which he started at the University of Fribourg at the border to the French-speaking part of Switzerland. He then continued and completed his studies at the University of Bern and also spent some months in Vienna, Austria. He undertook his MD thesis under the guidance of Prof. Ueli Wiesmann, a paediatrician who specialized in paediatric metabolic disorders at the University of Bern and who later became his mentor and supervisor as well as a very close friend. Primus started his initial training in paediatrics at the Children's Hospital Lucerne, in the heart of Switzerland, before he moved to the University Children's Hospital Bern
Prof. Primus-Eugen Mullis

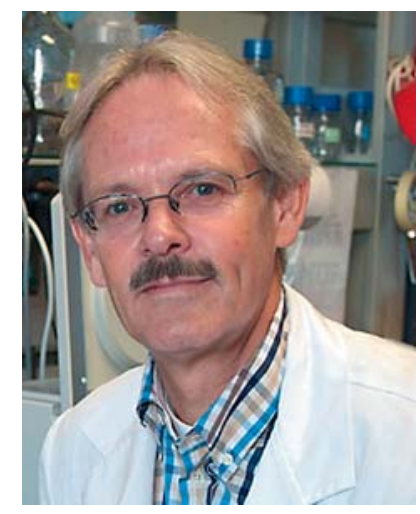

in 1986, which was at that time headed by the late Prof. Ettore Rossi. There he commenced his specialist training in paediatric endocrinology and diabetology with Prof. Klaus Zuppinger. However, it was one of his career highlights when Primus decided to go to London and train with Prof. Charles Brook. He got his first taste of molecular biology in 1988 while working in the laboratory of Prof. David Latchman at University College London. He then returned to Bern and completed his training in paediatric endocrinology and diabetology. He established a research group studying the molecular genetics of growth disorders and was one of the first to identify mutations in $P R O P 1$ in patients with congenital hypopituitarism. Having just returned, he was faced with the death of Prof. Zuppinger, and it was then left to him to carry on and build up a specialized unit for modern paediatric endocrinology and diabetology. The components of this future flagship included a high-quality in- and outpatient service, a routine hormone laboratory and a molecular research laboratory for studies of growth disorders and oth-

\section{KARGER}

E-Mail karger@karger.com

www.karger.com/hrp
(C) 2016 S. Karger AG, Basel

$1663-2818 / 16 / 0853-0219 \$ 39.50 / 0$ 
er genetic disorders of the pituitary gland. In addition, he provided undergraduate teaching at the medical school and training for paediatrics that was both general and specialized. He was appointed Professor and Head of the Division of Paediatric Endocrinology, Diabetology and Metabolism at the University Children's Hospital in Bern in 2000 and ran an active clinical division as well as an active research group working on the molecular basis of growth hormone deficiency, with particular focus on type 2 autosomal dominant growth hormone deficiency.

Additionally, Primus was a founding member of the Department of Clinical Research (DCR), a network connecting small groups of investigators who perform laboratory research within the University Hospital for sharing equipment and expertise. In addition, he was one of the pioneers who formed and led the Graduate School of Bern (GCB) for Cellular and Biomedical Sciences, which is just celebrating its 10th anniversary this year. In this function, he was a dedicated mentor for numerous trainees. Overall, he supervised many doctoral theses of MDs and trained several $\mathrm{PhD}$ students and postdoctoral fellows in his research laboratory. In addition, he granted specialized training in paediatric endocrinology and diabetology to more than 10 fellows, who now provide highquality care all over Switzerland, including a number of academic paediatricians.

Primus published more than 175 peer-reviewed publications and invited reviews and several book chapters and edited the Developmental Endocrinology book series. He had been an Associate Editor of Hormone Research in Paediatrics since 1996. He was a member of numerous learned societies and served on the councils of the International Growth Hormone Research Society and the Swiss Society for Endocrinology and Diabetology. He also served as Chairman of the Swiss Society for Paediatric Endocrinology and Diabetology. He was a Board Member of the Swiss National Science Foundation between 2000 and 2009, and a Member of the Swiss Academy of Medical Sciences since 2009. He also received a number of awards; those he was most proud of were the Cloetta Prize of the University of Zürich (1998) and the prestigious Research Award of the European Society for Paediatric Endocrinology awarded to him in 2007. Primus was an active member of ESPE and was much respected by his colleagues. He worked hard for the society, and his various roles over the years included his membership of the Programme Organising Committee, the coordination of the Developmental Endocrinology series of meetings, and membership of the steering committee of the ESPE Summer School. In addition to being an outstanding cli- nician and researcher, he was an excellent teacher and will be remembered by his many students for his teaching prowess.

Primus loved to watch, follow and perform sports. As an endocrinologist, he was therefore predestined to get involved in issues of doping. Thus, he served as an expert to the Swiss Olympic Committee for several years.

In 2007, Primus went on a 6-month sabbatical leave programme to Great Ormond Street Children's Hospital and the MRC National Institute for Medical Research in London; he was delighted to be in a city for which he had a great fondness and lived with some of his close friends in London during this short time. He pursued a research project on isolated growth hormone deficiency type II together with Prof. Iain Robinson at the MRC National Institute of Medical Research, Mill Hill, London. He returned to Bern refreshed, happy and proud to have received from those institutes a title of Honorary Professor and the status of Honorary Consultant.

Primus was also a proud father to two children, Daniel and Annina, who are both adults now. Although he was very busy at work, he was always involved with their care and dedicated time to his children. More recently, he and his second wife Pia both enjoyed travelling and being outdoors together. His favorite hobby outside work was trekking in the Swiss mountains, although the highest peaks he had climbed were the Kilimanjaro in Tanzania, Africa, and Mt. Blanc in France. A major skiing accident left him severely incapacitated for a while in 2004 . However, with his typical courage, he valiantly fought back to good health.

When Primus was challenged with a potentially lifethreatening diagnosis in 2014, he decided to keep this a secret shared by only his family and close friends. He carried on with his beloved profession and research as much as he could and was determined to conquer the disease. Sadly, he finally passed away on January 12,2016 , far too young and with so much that he could still have offered to the world.

Friends and colleagues will remember Primus for his intelligence, scientific rigour, warmth, kindness, wit, charm and generosity, as well as for his energy and enthusiasm. He had a great fun-loving streak and was a real prankster at times - all of us will have our favourite story to tell about him! Primus will be greatly missed by the paediatric endocrinology world, his family and colleagues, and his many friends and collaborators throughout the world.

Christa E. Flück, Bern Mehul Dattani, London Annina Mullis, Bern 